Univerzitet u Beogradu
Poljoprivredni fakultet
Institut za poljoprivrednu tehniku
Naučni časopis
POLJOPRIVREDNA TEHNIKA
Godina XLIV
Broj 4, 2019.
Strane: $60-72$

\title{
DESIGN AND DEVELOPMENT OF MECHANICAL DRIED CHILLIES COMPACTION MACHINE
}

\author{
Vishnu Vardhan Sidlagatta*1, John Wesley Bandi ${ }^{1}$ \\ ${ }^{1}$ AICRP on Post Harvest Engineering \& Technology, Acharya N.G. \\ Ranga Agricultural University, Bapatla, India
}

\begin{abstract}
Dried chillies are packed in gunny bags non-uniformly in different packing sizes. Dried chilies, being low bulk material occupies large volume, need to be compacted before it is bagged to gunny bags. Conventionally, dried chilies are compacted by labor in the field itself by tying gunny bag to a tripod stand and simultaneous filling of dried chilies and trampling by feet till overall weight of the bag reaches $40-45 \mathrm{~kg}$. Conventional method is highly labor intensive involves drudgery, low productive (3 laborers can compact a quantum of 8 bags per hour) and causes burning sensation to the labor. An attempt has been made to design and develop portable mechanical machine to compact dry chilies and bag. Evaluation of developed machine has been conducted at farmer's field in Guntur district of Andhra Pradesh - India. The capacity of the developed machine was found to be $18 \mathrm{bags} / \mathrm{h}$, technically feasible and economically viable. There is a saving of Rs 9.68 per bag in mechanized compaction and bagging process with an improvement in productivity over $150 \%$.
\end{abstract}

Key words: Chilli compaction machine, Power pack unit, Platen, Hydraulic motor, Bulk density, Moisture content

*Corresponding Author. E-mail address: vishnuvardhans@yahoo.com 


\section{INTRODUCTION}

Dry chilies are mostly pungent fruits of capsicum annum $L$ and capsicum frutescence majorly used as condiment or culinary for its pungency, spicy taste, besides the appealing color it adds to the food. It's powder is used in pickles, sauces, ketchup, essences, oleoresins and is an inevitable ingredient in all Indian dishes. The major chilli producers in the world are India, China, Pakistan, Morocco, Mexico, Turkey and Bangladesh. Chilies are mostly grown in all regions of India particularly Andhra Pradesh and Telangana contributing $2 / 3^{\text {rd }}$ of India's total production. Andhra Pradesh alone has a production of 8.83 lakh MT from 2.06 lakh hectares, which accounts for 24 percent of area and 47 percent of production in the country (www.indiastat.com, 2016-2017. statistics). In Andhra Pradesh, major production catchment include Guntur, Prakasam, Krishna and Kurnool districts. About $65 \%$ of the total chillies produced in India are exported to Srilanka, Bangladesh, Malaysia, USA, Nepal, Indonesia, UAE and Italy in the recent past (1).

In Andhra Pradesh, dried chillies are usually packed in gunny bags for transportation and storage. It is found that there is no uniformity in the packing size of chillies in the country. Packing material used and the capacity of packages are varying in different states. The size of gunny bag is generally $20-25 \mathrm{~kg}$ in North Eastern States and in Punjab (2). In Andhra Pradesh and Tamil Nadu, the pack size is about $40-45 \mathrm{~kg}$. Generally all the farmers use old gunny bags to pack chillies before selling. Only the exporters repack them in new gunny bags sometimes with polythene liners.

Dried chillies, being low bulk material occupies large volume, need to be compacted before it is bagged to gunny bags. Conventionally, dried chillies are compacted by farm labour in the field itself by tying gunny bag to a tripod stand and simultaneous filling of dried chillies and trampling by feet till overall weight of the bag reaches to $40-45 \mathrm{~kg}$.

Conventional method is highly labor intensive involves drudgery, low productive (3 labourers can compact a quantum of 8 bags per hour) and causes burning sensation to the labor trampling the chillies in bag. This paper aims to design and develop a dried chillies compaction machine in order to avoid drudgery in conventional compaction method using labourers and to conduct its evaluation studies.

\section{MATERIAL AND METHODS}

Basic principle employed for development of dried chillies compaction machine was hydraulic press to produce compressive force by means of hydraulic fluid using Pascal's principle (3)(4). Thus an attempt has been made to automate the process of press work using hydraulic mechanism in press machine. The inputs and outputs of the control system in hydraulic mechanism are solely mechanical such as reciprocating plunger operated by means of hydraulic components such as actuators to initiate the movement in the form of lever to apply manually so that the compaction of the dried chillies can be achieved in to and fro motion. Furthermore, direction control valves have been implemented to control the directions of piston movements and regulate the same. The principal parameters of the design included the maximum load, the distance the load resistance has to move, the system pressure, the cylinder area and the volume flow rate of the working fluid (5). 


\section{Design of hydraulic components}

The following assumptions were made in the design of hydraulic components:

\begin{tabular}{ll}
\hline Particulars & Assumption \\
\hline Stroke length & $1000 \mathrm{~mm}$ \\
Inner diameter of cylinder $\left(d_{c i}\right)$ & $110 \mathrm{~mm}$ \\
Size of moving platen & $360 \times 360 \mathrm{~mm}$ \\
Maximum working pressure & $1000 \mathrm{kPa}$ or $1 \mathrm{~N} / \mathrm{mm}^{2}$ \\
Allowable tensile stress for cast steel cylinder & $80 \mathrm{MPa}$ or $80 \mathrm{~N} / \mathrm{mm}^{2}$ \\
and end plate $\left(\sigma_{t c}\right)$ & \\
Allowable tensile stress for piston rod $\left(\sigma_{t p}\right)$ & $60 \mathrm{MPa}$ or $60 \mathrm{~N} / \mathrm{mm}^{2}$ \\
Allowable compressive stress for mild steel for ram $\left(\sigma_{c}\right)$ & $75 \mathrm{MPa}$ or $75 \mathrm{~N} / \mathrm{mm}^{2}$ \\
Allowable shear stress for mild steel for hinge $(\tau)$ & $45 \mathrm{MPa}$ or $45 \mathrm{~N} / \mathrm{mm}^{2}$ \\
\hline
\end{tabular}

\section{Maximum capacity of pressing machine (F)}

Maximum capacity of pressing machine was determined by multiplying maximum pressure with the contact area of moving platen.

\section{Pressure exerted inside the cylinder $(p)$}

Pressure inside cylinder $(p)$ was computed by equating to the work done by the cylinder

$$
\text { Thus, } \begin{aligned}
\mathrm{F} & =(\pi / 4) \times \mathrm{d}_{\mathrm{ci}}{ }^{2} \times p \\
p & =4 \mathrm{~F} / \pi \mathrm{d}_{\mathrm{ci}}{ }^{2}
\end{aligned}
$$
machine

where $\mathrm{d}_{\mathrm{ci}}$ is the diameter of inner cylinder, $\mathrm{F}$ is the maximum capacity of pressing

\section{Design of ram}

It is a round bar attached to piston at one end and to moving platen at other end and it moves in and out from cylinder for pushing and pulling operation. Let $d_{r}$ be the diameter of the ram and maximum force exerted by ram is given as

$$
\begin{aligned}
\sigma_{\mathrm{t}} & =(\pi / 4) \times \mathrm{d}_{\mathrm{r}}^{2} \times p . \\
\mathrm{d}_{\mathrm{r}} & =\sqrt{4} \sigma_{\mathrm{tc}} / \pi p
\end{aligned}
$$

where $\sigma_{\mathrm{tc}}$ is the tensile stress for cast steel

\section{Design of cylinder}

It is the important component of the machine. It develops pushing or pulling force to carry out desired operation using pressurized hydraulic fluid. For the compaction cum bagging machine, a double action cylinder is used which can take power stroke in forward as well as reverse direction. Both forward and reverse stroke was achieved by pumping oil under controlled pressure and flow direction from both oil port of cylinder.

Wall thickness of the cylinder $(t)$ can be found out by Lame's theorem (5)

$$
t=\left(\mathrm{d}_{\mathrm{ci}} / 2\right)\left\{\sqrt{ }\left[\left(\sigma_{\mathrm{tc}}+p\right) /\left(\sigma_{\mathrm{tc}}-p\right)\right]-1\right\}
$$




\section{Design of piston rod}

Let $d_{p}$ is the diameter of piston rod.

Force acting on piston rod is given as $(\mathrm{F})=(\pi / 4) \times \mathrm{d}_{\mathrm{ci}}{ }^{2} \times p=(\pi / 4) \times \mathrm{d}_{\mathrm{p}}^{2} \times \sigma_{\mathrm{tp}}$

$$
\mathrm{d}_{\mathrm{p}}=\sqrt{ }\left(\mathrm{d}_{\mathrm{ci}}^{2} \times p / \sigma_{\mathrm{tp}}\right)
$$

\section{Design of hinge pin}

Let $d_{h}$ is the diameter of hinge pin of piston rod. Load on the pin is equal to the force acting on piston rod and hinge pin is in double acting shear as per procedure stated (6), therefore

$$
\begin{gathered}
\mathrm{F}=2 \times(\pi / 4)\left(\mathrm{d}_{\mathrm{h}}\right)^{2} \tau=70.7\left(\mathrm{~d}_{\mathrm{h}}\right)^{2}\left(\text { Taking } \tau=45 \mathrm{~N} / \mathrm{mm}^{2}\right) \\
\mathrm{d}_{\mathrm{h}}=\sqrt{\mathrm{F} / 70.7}
\end{gathered}
$$

When cover is hinged to cylinder, one can use two hinge pins only diametrically opposite to each other. Thus, diameter of hinge pins for cover $d_{h c}=d_{h} / 2$

\section{Design of flat end cover}

Let $\mathrm{t}_{\mathrm{c}}$ is the thickness of end cover (7)

Force on end cover is given as $\mathrm{F}=\mathrm{d}_{\mathrm{ci}} \times \mathrm{t}_{\mathrm{c}} \times \sigma_{\mathrm{tc}}$

$$
\mathrm{t}_{\mathrm{c}}=\mathrm{F} /\left(\mathrm{d}_{\mathrm{ci}} \times \sigma_{\mathrm{tc}}\right)
$$

\section{Design of cylinder end cover plate}

The thickness $\mathrm{t}_{\mathrm{ce}}$, of the end-cover-plate, which is supported at the circumference by bolts and subjected to an internal pressure uniformly distributed over the area as per procedure suggested (6).

$$
\mathrm{t}_{\mathrm{ce}}=\mathrm{k}_{1} \mathrm{~d}_{\mathrm{ci}} \sqrt{ }\left(p / \sigma_{\mathrm{tc}}\right)
$$

where, the coefficient $\mathrm{k}_{1}$ depends on type of material of the plate and method of holding the edges, the value $\mathrm{k}_{1}$ is given as 0.44 for cast steel,

\section{Power output of cylinder}

Stroke length of piston is $\mathrm{L}$ and time required for working stroke is S. Distance moved by piston per second is given as $\mathrm{L} / \mathrm{S}$

Work done per second $=$ Force $\times$ distance moved by piston per second

$$
=\mathrm{F} \times \mathrm{L} / \mathrm{S}
$$

\section{Power of motor}

Power of required for motor was determined (8) by the following equation

Pump discharge $\left(\mathrm{Q}_{\mathrm{p}}\right)=$ Cross-Section Area of Cylinder $\left(\mathrm{m}^{2}\right) \times$ Working Speed $(\mathrm{m} / \mathrm{s})$

$$
=\pi / 4\left(\mathrm{~d}_{\mathrm{ci}}\right)^{2} \times \mathrm{L} / \mathrm{S}
$$

\section{Calculation of displacement of pump}

The displacement of the pump was calculated based on a 3-phase induction motor operating at N RPM. Assume a volumetric efficiency of $\eta_{\mathrm{v}}$. The pump must deliver sufficient flow to advance the cylinder at the maximum speed, hence displacement of pump was calculated as $\left(D_{p}\right)$

$\mathrm{D}_{\mathrm{p}}=\mathrm{Q}_{\mathrm{p}} / \mathrm{N} \eta_{\mathrm{v}}$ where, $\mathrm{N}$ is motor RPM,

Torque required to drive the pump at system pressure $(\mathrm{T})=\mathrm{D}_{\mathrm{p}} \cdot p / \eta_{\mathrm{m}}$ where, $\eta_{\mathrm{m}}$ is the mechanical efficiency)(9)(10)

Power of electric motor $=\mathrm{T}(\mathrm{N} \cdot \mathrm{m} / \mathrm{rad}) \cdot \mathrm{N}(2 \pi \mathrm{rad} / \mathrm{rpm})(\mathrm{min} / 60 \mathrm{~s}) / \eta_{\mathrm{e}}$ 


\section{RESULTS AND DISCUSSION}

\section{Physical properties of dried chillies before and after compaction in conventional method}

In a conventional method of compaction, a special bamboo tripod stand is formed and erected in the yards and gunny bag was held in between and a person tramples the pods by standing in the gunny bag, to achieve good compaction (11) (Figure 1). Generally, gunny bags used for bagging dried chillies have a diameter of $480 \pm 20 \mathrm{~mm}$ and a length of $1100 \mathrm{~mm}$. Certain properties of dried chillies before and after compaction and bagging was presented in Table 1. The data indicated that loose bulk density of the dried chillies was low and after compaction, the bulk density increased from 91 to $223 \mathrm{~kg} / \mathrm{m}^{3}$.

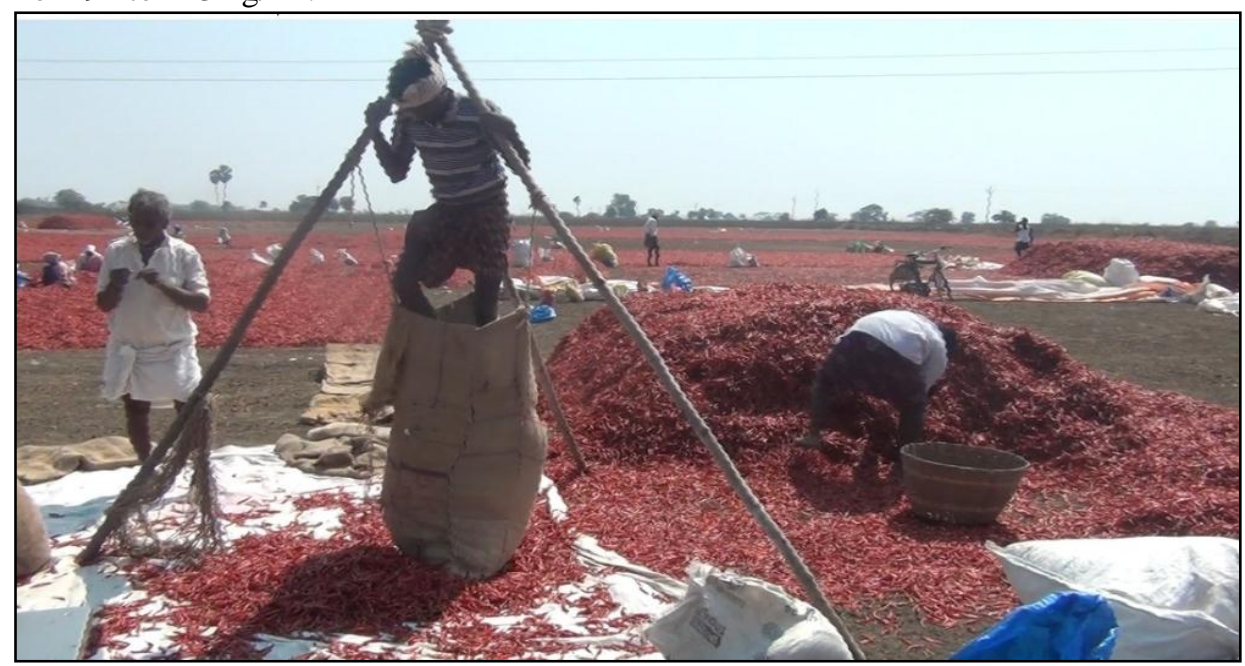

Figure 1. Conventional compaction and bagging of dried chillies

Table 1. Certain properties of dried chillies during conventional bagging

\begin{tabular}{lcc}
\hline Parameter & $\begin{array}{l}\text { Before compaction } \\
\text { and packing }\end{array}$ & After compaction and packing \\
\hline Weight $(\mathrm{kg})$ & $20.1 \pm 2.2$ & $39 \pm 2.2$ \\
Bulk density $\left(\mathrm{kg} / \mathrm{m}^{3}\right)$ & $91 \pm 14$ & $223 \pm 16$ \\
Moisture content $(\%$ w.b.) & $12.35 \pm 0.25$ & $12.35 \pm 0.25$ \\
\hline
\end{tabular}

\section{Determination of maximum force to achieve required compaction}

In conventional system, a farm labor of $70 \mathrm{~kg}$ body weight approximately tramples the dried chillies in the gunny bags around 35-40 times to achieve the bulk density of $230 \pm 5 \mathrm{~kg} / \mathrm{m}^{3}$. Pressure applied on the chillies was calculated as $0.54 \mathrm{~N} / \mathrm{mm}^{2}$ (Approximating force applied as $600 \mathrm{~N}$ and area of foot as $0.15 \times 0.075=0.011 \mathrm{~m}^{2}$ thus pressure applied was calculated as $54545 \mathrm{~N} / \mathrm{m}^{2}$ ).

Assuming factor of safety as 2, maximum compaction pressure required for design purposes was assumed as $1 \mathrm{~N} / \mathrm{mm}^{2}$ (or $1000 \mathrm{kPa}$ ). 
Important limitation regarding assumption of maximum compaction pressure is that the dried chillies pod should not break while compaction. Hence, compressive pressure for compaction of $1000 \mathrm{kPa}$ was considered for design purposes.

\section{Design of hydraulic components}

\section{Maximum capacity of pressing machine}

Maximum capacity of pressing machine is determined by multiplying maximum pressure with the contact area of moving platen.

Maximum capacity of pressing machine $=1000 \times 10^{3}\left(\mathrm{~N} / \mathrm{m}^{2}\right) \times(0.36)^{2}=129.6 \mathrm{kN}$ or $130 \mathrm{kN}$

Now, pressure inside the cylinder $(p)$. Load on pressing machine is equated to the work done by the cylinder

Thus, $130 \times 10^{3}(\mathrm{~N})=(\pi / 4) \times \mathrm{d}_{\mathrm{ci}}{ }^{2} \times p=(\pi / 4) \times(70)^{2} \times p$

$p=33.79 \mathrm{~N} / \mathrm{mm}^{2}$

\section{Design of ram}

It is a round bar attached to piston at one end and to moving platen at other end and it moves in and out from cylinder for pushing and pulling operation. Let $d_{r}$ be the diameter of the ram and maximum force exerted by ram is given as $\sigma_{\mathrm{tp}}=(\pi / 4) \times \mathrm{d}_{\mathrm{r}}^{2} \times p$.

On substitution of $\sigma_{\mathrm{t}}$ and $p$, the value of $\mathrm{d}_{\mathrm{r}}$ was obtained.

$60 \times 10^{3}(\mathrm{~N})=(\pi / 4) \times \mathrm{d}_{\mathrm{r}}^{2} \times 33.79$

$\mathrm{d}_{\mathrm{r}}=47.56 \mathrm{~mm}$ or $48 \mathrm{~mm}$

\section{Design of cylinder}

Let $d_{c o}$ is the outer diameter of hydraulic cylinder and $d_{c i}$ is the inner diameter of cylinder.

Assuming clearance of $20 \mathrm{~mm}$ between ram and cylinder bore, therefore, inner diameter of the cylinder $\left(\mathrm{d}_{\mathrm{ci}}\right)$.

$\mathrm{d}_{\mathrm{ci}}=\mathrm{d}_{\mathrm{r}}+$ clearance $=48+15=63 \mathrm{~mm}$ or say $70 \mathrm{~mm}$

Wall thickness of the cylinder $(t)$ can be found out by Lame's equation

$t=\left(\mathrm{d}_{\mathrm{ci}} / 2\right)\left\{\sqrt{ }\left[\left(\sigma_{\mathrm{tc}}+p\right) /\left(\sigma_{\mathrm{tc}}-p\right)\right]-1\right\}$

substituting the values of $\mathrm{r}_{\mathrm{ci}}, \sigma_{\mathrm{t}}$ and $p$,

$t=35 \times\{\sqrt{ }[(80.00+33.79) /(80.00-33.79)]-1\}=35 \times(1.569-1)=19.92 \mathrm{~mm}$ or $20 \mathrm{~mm}$

Diameter of outer cylinder $=\mathrm{d}_{\mathrm{ci}}+2 t=70+(2 \times 20)=110 \mathrm{~mm}$

\section{Design of piston rod}

Let $d_{p}$ is the diameter of piston rod.

Force acting on piston $\operatorname{rod}(\mathrm{F})=(\pi / 4) \times \mathrm{d}_{\mathrm{ci}}{ }^{2} \times p=(\pi / 4) \times(70)^{2} \times 33.79=130039.15 \mathrm{~N}$

Force acting on piston rod is also given as $=(\pi / 4) \times \mathrm{d}_{\mathrm{p}}{ }^{2} \times \sigma_{\mathrm{tp}}=(\pi / 4) \times \mathrm{d}_{\mathrm{p}}{ }^{2} \times 60=47.13 \mathrm{~d}_{\mathrm{p}}{ }^{2}$

Equating above two gives $d_{p}=\sqrt{ }(130039.15 / 47.13)=52.52 \mathrm{~mm}$ or say $52 \mathrm{~mm}$ 


\section{Design of hinge pin}

Let $d_{h}$ is the diameter of hinge pin of piston rod. Load on the pin is equal to the foce acting on piston rod and hinge pin is in double acting shear, therefore

$\mathrm{F}=2 \times(\pi / 4)\left(\mathrm{d}_{\mathrm{h}}\right)^{2} \tau=70.7\left(\mathrm{~d}_{\mathrm{h}}\right)^{2}$ (Taking $\left.\tau=45 \mathrm{~N} / \mathrm{mm}^{2}\right)$

$130039.15=70.7\left(\mathrm{~d}_{\mathrm{h}}\right)^{2}$

$\mathrm{d}_{\mathrm{h}}=42.88 \mathrm{~mm}$ or $44 \mathrm{~mm}$

When cover is hinged to cylinder, one can use two hinge pins only diametrically opposite to each other.

Thus, diameter of hinge pins for cover $\mathrm{d}_{\mathrm{hc}}=\mathrm{d}_{\mathrm{h}} / 2=44 / 2=22 \mathrm{~mm}$

\section{Design of flat end cover}

Let $t_{c}$ is the thickness of end cover.

Force on end cover is given as $\mathrm{F}=\mathrm{d}_{\mathrm{ci}} \times \mathrm{t}_{\mathrm{c}} \times \sigma_{\mathrm{tc}}$

$130039.15=70 \times \mathrm{t}_{\mathrm{c}} \times 80$

$\mathrm{t}_{\mathrm{c}}=23.22 \mathrm{~mm}$ or say $23 \mathrm{~mm}$

\section{Design of cylinder end cover plate}

The thickness $t_{c e}$, of the end-cover-plate, which is supported at the circumference by bolts and subjected to an internal pressure uniformly distributed over the area, is given by Eq. (2) as:

$\mathrm{t}_{\mathrm{ce}}=\mathrm{k}_{1} \mathrm{~d}_{\mathrm{ci}} \sqrt{ }\left(\mathrm{p} / \sigma_{\mathrm{tc}}\right)$,

where, the coefficient $\mathrm{k}_{1}$ depends on type of material of the plate and method of holding the edges, the value $\mathrm{k}_{1}$ is given as 0.44 for cast steel,

$\mathrm{t}_{\mathrm{ce}}=0.44 \times 70 \sqrt{ }(33.79 / 80)=20.01 \mathrm{~mm}$ or $20 \mathrm{~mm}$

\section{Power output of cylinder}

Stroke length of piston $=1.0 \mathrm{~m}$

Time required for working stroke $=24 \mathrm{~s}$

Distance moved by piston per second $=1.00 / 24(\mathrm{~m})=0.041 \mathrm{~m}$

Workdone per second $=$ Force $\times$ distance moved by piston per second

$$
=130039.15 \times 0.041=5331.60 \mathrm{Nm}
$$

Power output of the cylinder $=5331.60 \mathrm{Nm} / \mathrm{s}=5.33 \mathrm{~kW}$

\section{Platens}

The platens provide point of direct contact with the object being compressed. Hence, they are subjected to pure bending stress due to an equal and opposite couple acting in the same longitudinal plane. The design consideration is essentially for bending and consists primarily upon the determination of the largest value of the bending moment (M) and shear force (V) created in the beam which was found to be $45 \mathrm{kN} / \mathrm{m}$ and 150 $\mathrm{kN}$, respectively. These were computed using the adopted procedure (12). 
Bending moment of platen is given as

$\mathrm{M}=\mathrm{FL} / 4=130(\mathrm{kN}) \times 0.36 / 4(\mathrm{~m})=11.7 \times 10^{6} \mathrm{~N}-\mathrm{mm}$

Similarly, section modulus for a square platen is

$\mathrm{Z}=\mathrm{b}^{3} / 6=(0.36)^{3} / 6=7.776 \times 10^{6} \mathrm{~mm}^{3}$

Now bending stress acting upon platen is given as

$\sigma_{\mathrm{b}}=\mathrm{M} / \mathrm{Z}$, where $\mathrm{Y}$ is yield stress $(250 \mathrm{MPa})$

$\sigma_{\mathrm{b}}=11.7 \times 10^{6} / 7.77 \times 10^{6}=1.505 \mathrm{~N} / \mathrm{mm}^{2}$.

Factor of safety $=$ Yield stress $/$ Bending stress $=250 / 2.104=118.82$

\section{Power of motor}

Pump discharge $=$ Cross-Section Area of Cylinder $\left(\mathrm{m}^{2}\right) \times$ Working Speed $(\mathrm{m} / \mathrm{s})$ $=\pi / 4\left(\mathrm{~d}_{\mathrm{ci}}\right)^{2} \times$ working speed $(\mathrm{m} / \mathrm{s})$

$$
\begin{aligned}
& =\pi / 4(70 / 1000)^{2} \times 0.041(\mathrm{~m} / \mathrm{s})=157.78 \times 10^{-6} \mathrm{~m}^{3} / \mathrm{s} \\
& =0.157 \mathrm{Lps} \text { or } 9.42 \mathrm{Lpm}
\end{aligned}
$$

\section{Calculation of displacement of pump}

The displacement of the pump was calculated based on a 3- phase induction motor operating at 1750 RPM. Assume a volumetric efficiency of 0.70 . Note that the pump must deliver sufficient flow to advance the cylinder at the maximum speed,

$\mathrm{D}_{\mathrm{p}}=\mathrm{Q}_{\mathrm{p}} / \mathrm{N}_{\mathrm{v}}=9.42 \times 10^{-3}\left(\mathrm{~m}^{3} / \mathrm{min}\right) /[1750(\mathrm{Rev} / \mathrm{min}) \times 0.70]=7.68 \times 10^{-6} \mathrm{~m}^{3} / \mathrm{rev}$

Torque required to drive the pump at system pressure:

$(\mathrm{T})=\mathrm{D}_{\mathrm{p}} \cdot p / \eta_{\mathrm{m}}$ (Assuming $\left.\eta_{\mathrm{m}}=0.7\right)$

$=7.68 \times 10^{-6}\left(\mathrm{~m}^{3} / \mathrm{rev}\right)(\mathrm{rev} / 2 \pi \mathrm{rad}) \times 2 \times 10^{6}\left(\mathrm{~N} / \mathrm{m}^{2}\right) / 0.7=3.494 \mathrm{~N} \cdot \mathrm{m} / \mathrm{rad}$

Power of electric motor $=\mathrm{T}(\mathrm{N} . \mathrm{m} / \mathrm{rad}) . \mathrm{N}(2 \pi \mathrm{rad} / \mathrm{rpm})(\mathrm{min} / 60 \mathrm{~s}) / \eta_{\mathrm{e}}$ $=3.494 \times 1750 \times 2 \pi /(60 \times 0.7)=914.28 \mathrm{~W}$ or $0.91 \mathrm{~kW}$ or $1.22 \mathrm{HP}$ $=$ or say $2.0 \mathrm{HP}$ electrical motor was selected.

\section{Design of hydraulic power pack unit}

Reservoir capacity: Tank capacity could be between 3 to 10 times of the pump discharge capacity. Thus, a tank capacity of 3 times of pump discharge capacity i.e., 30 $\mathrm{L}$ was selected. An oil reservoir tank of size $0.45 \times 0.38 \times 0.38 \mathrm{~m}$ was fabricated to hold hydraulic oil. Bottom of tank has sloping, where drain plug was provided. This facilitate removal of all contamination settled at bottom, when oil is drained-out. Further, externally visible oil level indicator was provided. Further, tank was provided with airbreather filler assembly and return line filter. Tank was provided with suction filter and baffle plate to protect pump from sucking heavy or light contamination returning to tank along with exhaust oil.

A relief valve with maximum pressure setting of $2 \mathrm{MPa}$ was provided at delivery side of pump to avoid any pressure build-up. A pump operating without relief valve is bound to cause an accident or damage to system or for itself.

A single manifold block has connection port for connecting pump, exhaust port, and two oil port for cylinder, and on its various ground surface provision to mount the valves. After providing manifold and relief valve, a direction control valve is fitted on it. Oil is filled through filter up to maximum level of oil level indicator. 
The technical specifications of dried chillies compaction machine are shown in Table 2 and specifications of components of manifold block are depicted in Table 3. Various components of mechanical dried chillies compaction machine is shown in Figure 2.

Table 2. Technical specifications of the dried chillies compaction machine

\begin{tabular}{ll}
\hline Description & Specification \\
\hline Type & Hydraulic double acting cylinder \\
& compaction machine \\
Stroke length & $1 \mathrm{~m}$ \\
Compaction pressure & $1000 \mathrm{kPa}$ \\
Maximum pressure & $2000 \mathrm{kPa}$ \\
Cylinder diameter & $110 \mathrm{~mm}$ \\
Piston diameter & $40 \mathrm{~mm}$ \\
Moving platen dimension & $360 \times 360 \mathrm{~mm}$ \\
Power pack unit hydraulic oil capacity & $30 \mathrm{~L}$ \\
Dimensions & $965 \times 920 \times 2850 \mathrm{~mm}(L \times W \times H)$ \\
Capacity of hopper & $7 \mathrm{~kg}$ \\
Power & $2 \mathrm{HP}$ single phase \\
\hline
\end{tabular}

Table 3. Specifications of components of manifold block

\begin{tabular}{ll}
\hline Component & Technical specifications \\
\hline Hydraulic suction pipe & Connect thread size $G 3 / 8 ;$ shapes $($ Curve $-73,29$ \\
& mm; Straight $-120,180,280,320 \mathrm{~mm}$ \\
Hydraulic return pipe & Connect thread size M12, Shape straight -120, \\
& $180,280,320 \mathrm{~mm}$ \\
\hline
\end{tabular}

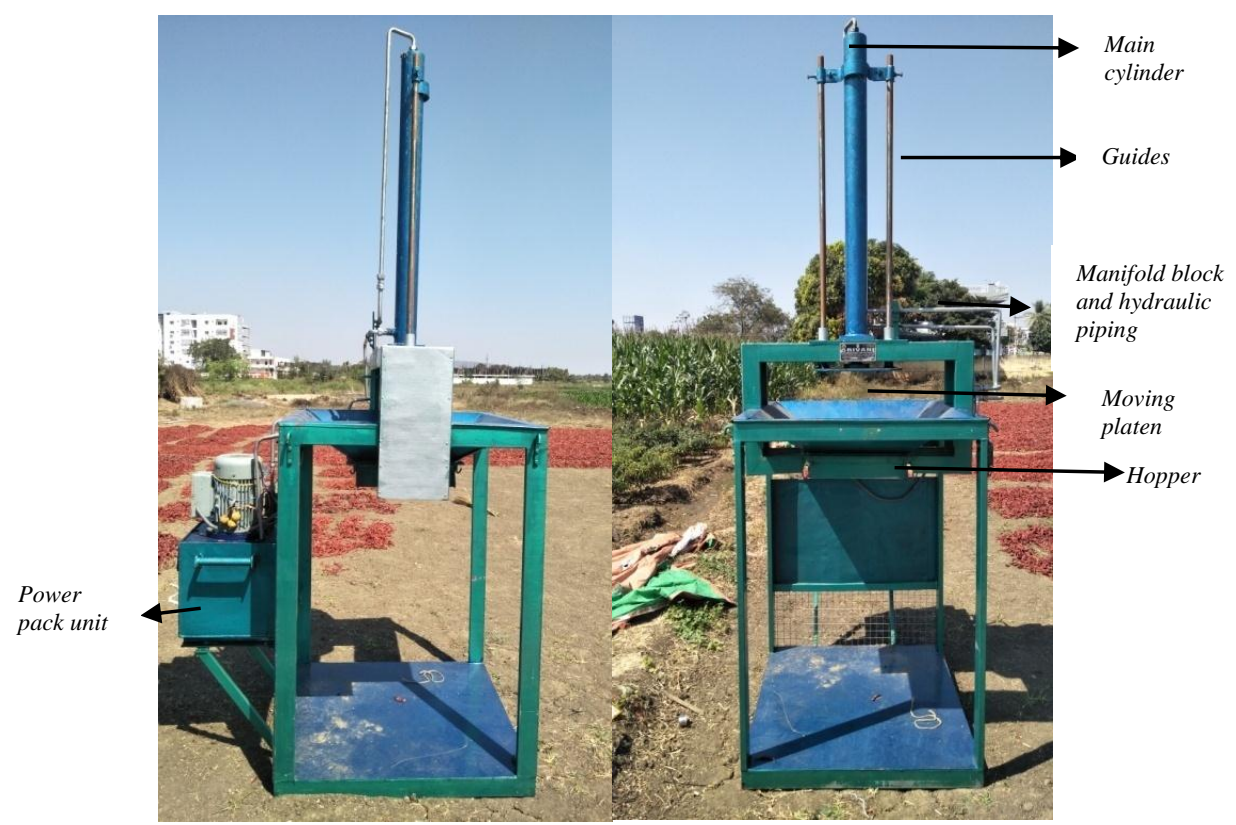

Figure 2. Mechanical dried chillies compaction and bagging machine 

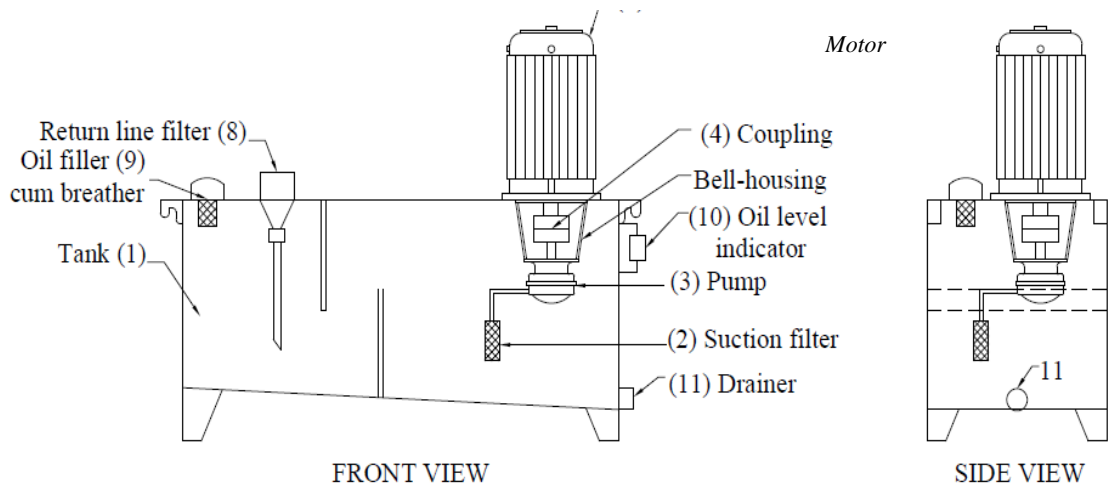

SIDE VIEW

Figure 3. Various components of power pack unit

\section{Performance evaluation of the developed compaction machine}

The details of the evaluation of chillies compaction machine was shown in Table 4. Time required for compaction and bagging of dried chillies was recorded to vary from 3 to $3.5 \mathrm{~min}$ where as in conventional method, it varied from 8.5-10 min. Average bulk density of chillies compacted in mechanical system was noted as $239.4 \mathrm{~kg} / \mathrm{m}^{3}$ and average compacted weight of chillies was recorded as $42 \mathrm{~kg}$ (Figure 4). The capacity of mechanized compaction and bagging unit worked out to be $18 \mathrm{bags} / \mathrm{h}$.

The economic analysis of conventional and mechanized compaction cum bagging of dried chillies shows that the cost of compaction and bagging in conventional system was Rs. 30/ bag of 40-45 kg where as in mechanized system; the cost was worked out to be Rs.20.31 per bag. There was a saving of Rs.9.68 per bag in mechanized compaction and bagging. Total savings in a day of $10 \mathrm{~h}$ of working, was estimated to be Rs. 2343. Further, productivity in mechanized system was worked out be $150 \%$ over conventional system. Economic analysis suggested that return on investment was worked out to be $70.3 \%$ with a payback period of 1.42 years.

Table 4. Evaluation of mechanical dried chillies compaction machine

\begin{tabular}{lcc}
\hline Parameter & $\begin{array}{l}\text { Mechanical compaction cum bagging } \\
\text { method }\end{array}$ \\
\hline Time for compaction and bagging per bag (min) & $3.0-3.5$ \\
Capacity (bags/ $h$ ) & $18 \pm 1$ \\
Breakage of pods & Nil \\
Weight of the bag & $42.0 \pm 2.2$ \\
Bulk density & $239.4 \pm 7.2$ \\
\hline
\end{tabular}




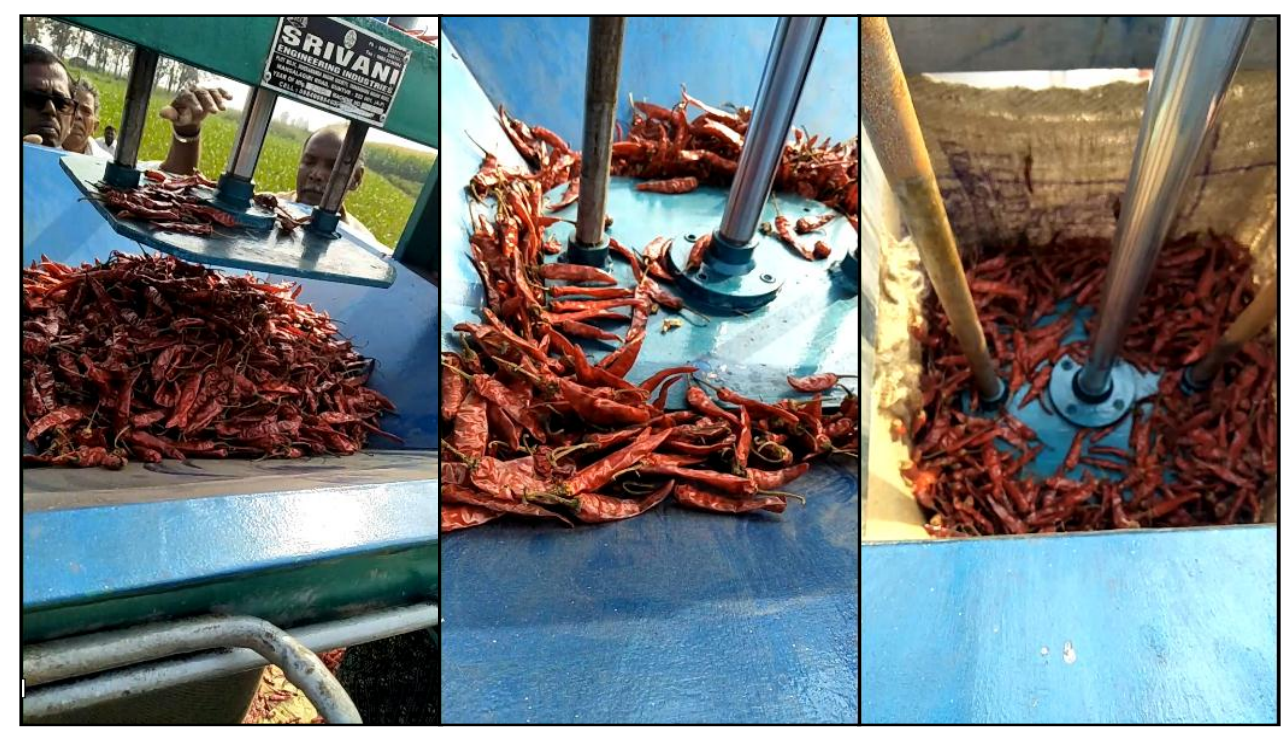

Figure 4. Compaction of dried chillies in gunny bags using compaction machine

\section{CONCLUSIONS}

Conventional method of compaction and bagging of dried chillies is low productive and involves drudgery and burning and day long scorching sensation to the laborers involved. An attempt was made to develop a mechanical compaction machine for packing of capacity $18 \mathrm{bags} / \mathrm{h}$. Evaluation of developed machine has been conducted at farmer's field. Developed machine is technically feasible and economically viable. There is a saving of Rs. 9.68 per bag in mechanized compaction and bagging process with an improvement in productivity over $150 \%$.

\section{REFERENCES}

[1] Prabhavathi, Y., Kishore, N.T.K. and Seema. (2013). Analysis of supply chain of Spices in India: A case study. International J.of Scientific and Research Publications, 3(9): 1-4.

[2] Karpate, R. (2010). Post harvest profile of chilli. Published by Directorate of marketing and Inspection, Department of Agriculture and Cooperation, Ministry of Agriculture, Government of India.

[3] Vyshnav, A., Lathiya, P. and Sarvaiya, M. (2016). Design optimization of hydraulic plate press using finite element analysis. Int. Journal of Engineering Research and Applications www.ijera.com. 6( 5): pp. 58-66.

[4] Malipatil, S.S., Potdar, Y.N. and Mattikalli, S.S. (2014). Analysis and structural optimization of $\mathrm{H}$ frame hydraulic press. International Journal of Innovative Science, Engineering \& Technology, 1(5): pp. 256-361. 
[5] More, D.A., Chhapkane, N.K. and Kolhe, R. (2015). Design, development and optimization of hydraulic press. International Journal for Research in Applied Science \& Engineering Technology (IJRASET). 3(VI): pp. 902-908

[6] Khurmi, R.S. and Gupta, J.K. (1997). A textbook of machine design. Eurasia Publ., New Delhi, India.

[7] Sumaila, M. and Ibhadode, A.O.A. (2011). Design and Manufacture of a 30-ton Hydraulic Press. Australian Journal of Technology, 14(3): pp.196-200

[8] Eltantawie, M.A.E. (2013). Design and manufacture of hydraulic bending press. International Journal of Mechanical Engineering and Robotics Research, 2(1): pp. 1-9.

[9] Israr, M., Tiwari, A. and Gangele, A. (2015). Design and optimization of power press machine. International Journal of Engineering \& Technology Innovations. 2(1).ISSN (Online): pp. 2348-0866.

[10] Rahul, J., Sayali, S., Sudhir, B., Priyanka, S. and Manoj, G.(2017). Design of 30 ton capacity press capacity. International Journal of Advance Engineering and Research Development, 4(3): pp. 198-204.

[11] Satyanarayana Ch V V; Sukumaran C R. (2002). Post harvest profile of chillies. Technical bulletin published by AICRP on Post Harvest Technology, Bapatla.

[12] Beer F P; Johnston E R. (1992). Mechanics of materials. $2^{\text {nd }}$ ed., McGraw- Hill, London, England, UK.

\title{
PROJEKTOVANJE I RAZVOJ MAŠINE ZA MEHANIČKO SABIJANJE OSUŠENE ČILI PAPRIKE
}

\author{
Vishnu Vardhan Sidlagatta*1, John Wesley Bandi ${ }^{1}$ \\ ${ }^{1}$ AICRP on Post Harvest Engineering \& Technology, Acharya N.G. Ranga Agricultural \\ University, Bapatla, India
}

Sažetak. Osušene čili paprike se pakuju (konvencionalno sušenje u polju na vazduhu) u vreće bez nekog određenog oblika u različitim veličinama pakovanja (vreće). $\mathrm{Na}$ ovaj način osušene čili paprike imaju veliku ukupnu zapreminu, koju treba smanjiti na manju zapreminu, pre nego što se upakuju u vreće. Tradicionalno se osušeni materijal čili paprika sabija na samom polju gaženjem nogama radnika sve dok ukupna težina vreće ne dostigne 40-45 kg. Ova konvencionalna metoda je radno intezivna, ima malu produktivnost (3 radnika sabijanjem napune 8 vreća/čas), i izaziva snažan neprijatan i nelagodan osećaj ljutine kod radnika.

Dizajnirana je i napravljena prenosna mehanička mašina za sabijanje (kompakciju) osušenog čilija u vreće. Ispitivanje ove razvijene kompakt mašine je obavljeno na polju u okrugu Guntur u državi Andhra Pradesh - Indija. 
Kapacitet ove razvijene mašine je 18 vreća/čas, što tehnički je izvodljivo i ekonomski isplativo.

Ušteda od 9,68 Rs po vreći u postupku mehanizovanog sabijanja i sakupljanja osušene čili paprike ima poboljšanje produktivnosti od preko $150 \%$.

Ključne reči: Mašina za sabijanje Chilli paprika, pogonski motor, valjak, hidraulični motor, zapreminska težina, sadržaj vlage.

\begin{tabular}{|c|c|}
\hline $\begin{array}{l}\text { Prijavljen: } \\
\text { Submitted: }\end{array}$ & 28.05 .2019 \\
\hline $\begin{array}{l}\text { Ispravljen: } \\
\text { Revised: }\end{array}$ & 20.07.2019. \\
\hline $\begin{array}{l}\text { Prihvaćen: } \\
\text { Accepted: }\end{array}$ & 21.10 .2019 \\
\hline
\end{tabular}

